\title{
Microbiological Quality of Fresh Nopal Juice
}

\author{
Ana María Hernández-Anguiano ${ }^{1, *}$, Patricia Landa-Salgado ${ }^{1}$, Carlos Alberto Eslava-Campos ${ }^{2,3}$, \\ Mateo Vargas-Hernández ${ }^{4}$ and Jitendra Patel ${ }^{5}$ \\ 1 Phytopathology, Graduate College, Carr. Mexico-Texcoco km 36.5, Montecillo, Texcoco 56230, Mexico; \\ patylanda@gmail.com \\ 2 Departamento de Salud Pública, Facultad de Medicina, National Autonomous University of \\ Mexico (UNAM), University Avenue No. 3000, Ciudad Universitaria, Coyoacan, Mexico City 04510, Mexico; \\ eslava@unam.mx \\ 3 Unidad de Hemato Oncología e Investigación, Hospital Infantil de México “Federico Gómez" /División de \\ Investigación, Facultad de Medicina UNAM. Dr. Márquez 162, Col. De los Doctores, \\ Cd. de Mexico 06720, Mexico \\ 4 Soil Science, Autonomous University of Chapingo, Km 38.5 Carretera Mexico-Texcoco, \\ Chapingo 56230, Mexico; vargas_mateo@hotmail.com \\ 5 U.S. Department of Agriculture, Agricultural Research Service, Beltsville, MD 20705, USA; \\ Jitu.Patel@ARS.USDA.GOV \\ * Correspondence: ahernandez@colpos.mx; Tel.: +52-595-95-20200 (ext. 1606) \\ Academic Editor: Giuseppe Comi \\ Received: 24 October 2016; Accepted: 1 December 2016; Published: 10 December 2016
}

\begin{abstract}
The consumption of fresh nopal cactus juice is widely popular among health-conscious consumers in Mexico. The juice is prepared from fresh cladodes that have only been rinsed with tap water and are not subjected to a pasteurization or terminal bacterial reduction process. The aim of this study was to evaluate the microbial quality of commercially available fresh juices $(n=162)$ made with nopal in Texcoco, State of Mexico, during the summer and spring season. Standard microbiological methods, the PCR technique and the serological method were used for isolation and identification of bacteria. All samples contained total coliforms and 91\% were positive for Escherichia coli. Although total coliforms and E. coli were detected throughout the study, their populations were significantly lower $(p<0.05)$ in winter and spring, respectively. Citrobacter youngae was found in $20 \%$ of the samples, an unidentified species of Citrobacter in 10\%, C. freundii and Proteus mirabilis in 3\%, and Salmonella Javiana in 1\%. The presence of these microorganisms, especially Salmonella, in the nopal juices is unacceptable due to its health significance. The information generated in this study is relevant for human health risk assessment associated with the consumption of unpasteurized nopal juices and potential interventions to minimize pathogen contamination.
\end{abstract}

Keywords: cactus; Opuntia-ficus indica; nopal juice; Citrobacter; E. coli; total coliforms; Salmonella

\section{Introduction}

Nopal cactus (Opuntia ficus-indica) (L.) Mill. (Cactaceae) is a native species of economic and social importance in Mexico. The tender stems (10-15 cm) of nopal, commonly known as "nopales", "nopalitos" or "cladodes" (flattened stems), are used as main ingredients in a wide variety of cooked (soups and sauces) or raw (salads and juices) food products due to their high content of dietetic fiber, minerals, vitamins and antioxidants [1].

The consumption of fresh nopal juice, alone or combined with other fresh fruits and vegetables, is widely popular among health-conscious consumers due to its purported health benefits. In addition to its nutritive value, the juice made from nopal is also consumed for its medicinal properties such as antiulcer and hypoglycemic activity [2,3], skin healing properties [4], and of its ability to reduce 
blood serum cholesterol [1]. Therefore, it is consumed by people, including those with type 2 diabetes mellitus, either in natural form, blended with water or mixed with other products such as pineapple, orange or grapefruit [5].

In the central zone of Mexico, commercial vendors in the buildings and local street stands offer fresh nopal juice for immediate consumption or to be consumed later. These vendors prepare juice from fresh nopal cladodes that have only been rinsed with tap water and the juice not subjected to a pasteurization or terminal bacterial reduction process. Fresh cattle manure is commonly used for soil fertility in traditional nopal agricultural farming practices. Hernandez and others [6] have reported the persistence of Salmonella in fresh nopal cladodes harvested at the farms following traditional farming practices. Potential contamination of nopal cladodes by Salmonella and other enteropathogens via soil at the farm level can cause outbreaks of foodborne illnesses as unpasteurized nopal juice is consumed. In the absence of terminal treatment for removing pathogens from nopal cladodes, the fresh juices made with nopal can be a vehicle for pathogens such as Salmonella and others [7,8]. Previous studies have reported the presence of bacterial pathogens in unpasteurized beverages prepared with fresh fruits and vegetables [9-12]. The main aim of this study was to evaluate the microbiological quality of fresh juices made with vegetable nopal sold at two commercial stands in the central zone of Texcoco, State of Mexico.

The information generated in this study is relevant for developing new interventions for bacterial reduction in fresh juice and for risk assessment for human health represented by the consumption of fresh unpasteurized nopal juice.

\section{Materials and Methods}

\subsection{Sampling of Fresh Juice}

Freshly prepared nopal juice samples $(n=162)$ were collected every month during June 2009 to May 2010 from commercial stands in the central zone of Texcoco, State of Mexico. Two stands were chosen based on a daily fresh nopal juice availability, potable water availability for juice preparation, and hygienic practices. One of the stands (stand A) located inside the building had potable tap water available whereas the other stand (stand B) is on the local street did not have tap water and had potential for airborne contamination in outside environment. Usually stand A served more than 10 types of fresh nopal juices, and stand B, just one type, during the sampling year. Types of fresh nopal juices analyzed in this study are shown in Table 1. A $500 \mathrm{~mL}$ fresh nopal juices samples, prepared from chopped nopal cladodes, without spines, and blended with fresh squeezing citric juice and/or a mix of fresh fruits and vegetables, were collected at both stands (138 samples from Stand A and 24 from stand B) in Styrofoam container sanitized with alcohol. Usually during the summer, fall and winter season, stand A served the first 12 types of fresh nopal juices indicated in Table 1 but not the following seven type of juices. In contrast, during the spring season of 2010 this stand served the last seven type of juices but not the first 12 types. At each sampling point, nopal cladode juice was prepared with natural water to determine reference microbial quality of cladode. The juice samples were transported on ice, maintained on ice or in refrigeration in the laboratory and processed within $2 \mathrm{~h}$ of sampling time.

Table 1. Characteristics of fresh nopal juices collected monthly from June 2009 to May 2010.

\begin{tabular}{ccc}
\hline Stand & Juice Composition & Recommendation * \\
\hline A & In building (A) & \\
A & Nopal, natural water & \\
A & Nopal, oats, orange and apple & Cholesterol \\
A & Nopal, broccoli, cabbage, asparagus and grapefruit & Cholesterol \\
A & Nopal, aloe vera, grapefruit and xoconostle & Glucose \\
\hline
\end{tabular}


Table 1. Cont.

\begin{tabular}{ccc}
\hline Stand & Juice Composition & Recommendation* \\
\hline A & In building (A) & \\
A & Nopal, garlic, lemon, parsley and pineapple & Reumas \\
A & Nopal, celery, sugar beet and pineapple & Slim down \\
A & Nopal, celery, lemon, parsley and carrot & Clean stomach \\
A & Nopal, squash, orange, cucumber and pineapple & Kidneys \\
A & Nopal, natural water, aloe vera and xoconostle & Matrix and cysts \\
A & Nopal, celery, parsley and pineapple & Diet \\
A & Nopal, prunes, flaxseed, papaya and orange & Constipation \\
A & Nopal, natural water, parsley and sugar beet & High triglycerides \\
A & Nopal, celery, honey, orange and pineapple & Diet \\
A & Nopal, oats, apple, honey and orange & Cholesterol 1 \\
A & Nopal, alfalfa, lemon, honey, orange and pineapple & Cholesterol 2 \\
A & Nopal, natural water, aloe vera and xoconostle & Diabetes \\
A & Nopal, olive oil, sugar beet, flax, papaya, honey and orange & Laxative \\
A & Nopal, aloe vera, grape fruit and xoconostle & Cysts \\
& Nopal, prunes, flaxseed, honey, papaya and orange & Constipation \\
\hline B & In street booth (B) & \\
B & $*$ Nopal, natural water & Diet \\
\hline
\end{tabular}

${ }^{*}$ Health recommendation were posted by vendors and not necessarily evaluated by authors.

\subsection{Microbiological Analysis}

Prior to the microbiological analysis, the $\mathrm{pH}$ of each sample was determined with a potentiometer (Hanna Instruments, Sarmeola di Rubano, Italy). Because most of the juice nopal types were dense, samples for microbiological analysis were taken by weight $(\mathrm{g})$ instead of volume $(\mathrm{mL})$. To determine total coliforms using the plate count technique [13], $25 \mathrm{~g}$ of each juice sample was mixed with $225 \mathrm{~mL}$ of $0.1 \%$ buffered peptone water (BPW, Becton Dickinson, Cuautitlan Izcally, Mexico) in a sterile bottle and manually mixed for $15 \mathrm{~s}$. Serially diluted juice suspensions were spread-plated on MacConkey Agar (MA, Becton Dickinson, Cuautitlán Izcally, Mexico). After $24 \mathrm{~h}$ incubation at $37^{\circ} \mathrm{C}$, lactose fermenting red colonies were counted as total coliforms. Presumptive pink or red E. coli colonies on MacConkey agar plates were identified following comparative pink or red colonies of reference strain E. coli 042 on MacConkey agar.

The isolation of presumptive Salmonella was carried out in non-selective pre-enrichment medium and selective enrichment medium [14]. For the non-selective pre-enrichment, $10 \mathrm{~g}$ of each sample was mixed with $90 \mathrm{~mL}$ tryptic soy broth (TSB, Bioxon) in sterile bottle and incubated overnight at $37^{\circ} \mathrm{C}$. Following incubation, $1 \mathrm{~mL}$ each was transferred to $9 \mathrm{~mL}$ of tetrathionate base broth (TB, Becton Dickinson), and $9 \mathrm{~mL}$ of Vassiliadis-Rappaport broth (VRB, Becton Dickinson) and incubated at $37^{\circ} \mathrm{C}$ for 18-24 h. A loopful of selectively enriched samples were streaked on Hektoen enteric agar (HEA, Bioxon) and on bright green agar (BGA, Bioxon) plates and incubated at $37^{\circ} \mathrm{C}$ for $24 \mathrm{~h}$. Following incubation, select Salmonella colonies that are green or blue-green, with or without a black center, or completely black colonies [15] in HEA were transferred in Luria-glycerol $(20 \%, \mathrm{v} / \mathrm{v})$ at $-20^{\circ} \mathrm{C}$. These Salmonella colonies were confirmed with biochemical tests using Vitek automated system (BioMérieux, Hazelwood, MO, USA) and the polymerase chain reaction (PCR) technique. From each positive juice sample, at least two isolates were retained for further confirmation and characterization.

\subsection{Biochemical Identification and Characterization}

Eighty-eight presumptive Salmonella isolates preserved in Luria-glycerol (20\%) were reactivated in TSB and grown in HEA for further characterization. Presumptive Salmonella isolates were evaluated for indole production, methyl red, Voges-Proskauer test and citrate production, mobility analysis, 
hydrogen sulphate production, deamination and decarboxylation of lysine, sugar production and fermentation of sugars (glucose, lactose and saccarose) [16].

Cryopreserved Salmonella isolates were reactivated in blood gelose agar for confirmation of biochemical identity with the Vitek system (BioMerieux, Hazelwood, MO, USA). The reactivated cultures were grown in soy tryptone agar at $37^{\circ} \mathrm{C}$ for $24 \mathrm{~h}$, subsequently diluted in $0.4 \%$ saline solution and then adjusted to $1 \mathrm{OD}$ in the McFarland scale for the automatic card completion of Gram Negative (GN) cards. After $24 \mathrm{~h}$ at $37^{\circ} \mathrm{C}$, Vitek system identified isolates based on biochemical results.

\subsection{Serological and Molecular Confirmation}

One of the presumptive Salmonella isolates and phenotypically identified by Vitek system as Salmonella was sent to the Bacteriology Laboratory of the Department of Public Health of the Department of Medicine of UNAM to determine the serogroup by somatic and flagellar agglutination method [17]. For the amplification of the InvA gene of Salmonella [18], the primers Sal-3 and Sal-4 were used with PCR Core System 1 (Promega, Madison, WI, USA). Cellular lysate samples (raw DNA) of Salmonella Javiana strain, raw DNA of three strains of the undefined genus between C. youngae and C. freundii, and raw DNA of a C. freundii strain, all of them isolate from nopal juice samples, were analyzed with PCR method [18]. Lysates of S. enterica serotype Typhimurium ATCC23564 and E. coli 042 were used as positive and negative controls, respectively.

\subsection{Statistical Analysis}

The $\mathrm{pH}$ values and microbiological results of samples ran in triplicate were analyzed with SAS program (Windows 9.4). Analyses of variance due to seasonal effect, type of juice, and their interactions were conducted using PROC GLM and multiple comparison of means based on the honest significant difference of Tukey at $5 \%$ significance level $(p=0.05)$.

\section{Results and Discussion}

The 162 samples of fresh juice made from fresh nopal had an average $\mathrm{pH}$ of 4.6, with a range of 4.1 to 5.1 depending on the type of juice. When the $\mathrm{pH}$ values were analyzed, significant differences $(\alpha=0.05)$ were found among the $\mathrm{pH}$ of the juices (Table 2).

Total coliforms were detected in all juice samples (100\%) with an average value of $4.5 \mathrm{Log}$ CFU $/ \mathrm{mL}$. The total coliforms varied significantly with the type of juice and season of sample collection. The nopal, celery, lemon, parsley and carrot juice had the highest total coliforms (5.6 Log CFU/mL); the nopal, garlic, lemon, parsley and pineapple juice had the lowest coliforms (3.3 Log CFU/mL, Table 2). While the total coliforms varied in different types of juices, the average coliforms in samples collected in winter $(4.1 \mathrm{Log} \mathrm{CFU} / \mathrm{mL}$ ) were significantly lower than those samples obtained in the summer season (Figure 1A). Presumptive E. coli colonies were detected throughout the year, but their count was significantly lower $(p<0.05)(1.6 \mathrm{Log}$ CFU/mL) during the spring-2010 season (Figure 1B). Presumptive E. coli was detected in 148 of 162 samples (91\%) with an average of $3.0 \mathrm{Log}$ CFU $/ \mathrm{mL}$. Most of the E. coli- negative nopal juice samples were collected during April and May of 2010. Similar to the total coliforms, E. coli populations were also significantly influenced by the type of juice and season of sample collection. The samples of nopal, celery, lemon, parsley and carrot juice had the highest presumptive E. coli populations ( $4.8 \mathrm{Log} \mathrm{CFU} / \mathrm{mL}$ ) whereas the least presumptive E. coli (0.9 Log CFU $/ \mathrm{mL}$ ) populations were detected in nopal, olive oil, sugar beet, flax, papaya, honey and orange juice samples (Table 2).

According to the Norm NOM-127-SSA1 standards [19], potable tap water should be free from total coliforms and E. coli. Although total coliforms do not necessarily represent a risk for the health of consumers, the higher coliforms in fresh nopal juice indicate the poor microbial quality of nopal, potable water, or an inadequate hygienic process during their preparation. Similarly, the correlation between generic E. coli and enteric pathogens is unknown; however, the recent Food Safety Modernization Act (FSMA) by the US-FDA requires monitoring irrigation water for generic E. coli to control enteric 
pathogens on fresh produce [20]. It is possible that the extent of contamination could be dependent on how the juice was prepared [21]. The collection of potable water at each juice-sampling schedule and subsequent water analysis could have helped in identifying the role of water in the contamination of fresh juice. Further, the poor hygiene practices, such as washing hands or equipment used during preparation, could also be involved in the contamination of the juices. Our results on the lower recovery of coliforms during cold seasons are in agreement with the results reported by Mollie and Groisman [22] who observed the seasonal effects of Salmonella and E. coli survival in fresh vegetables following manure application.
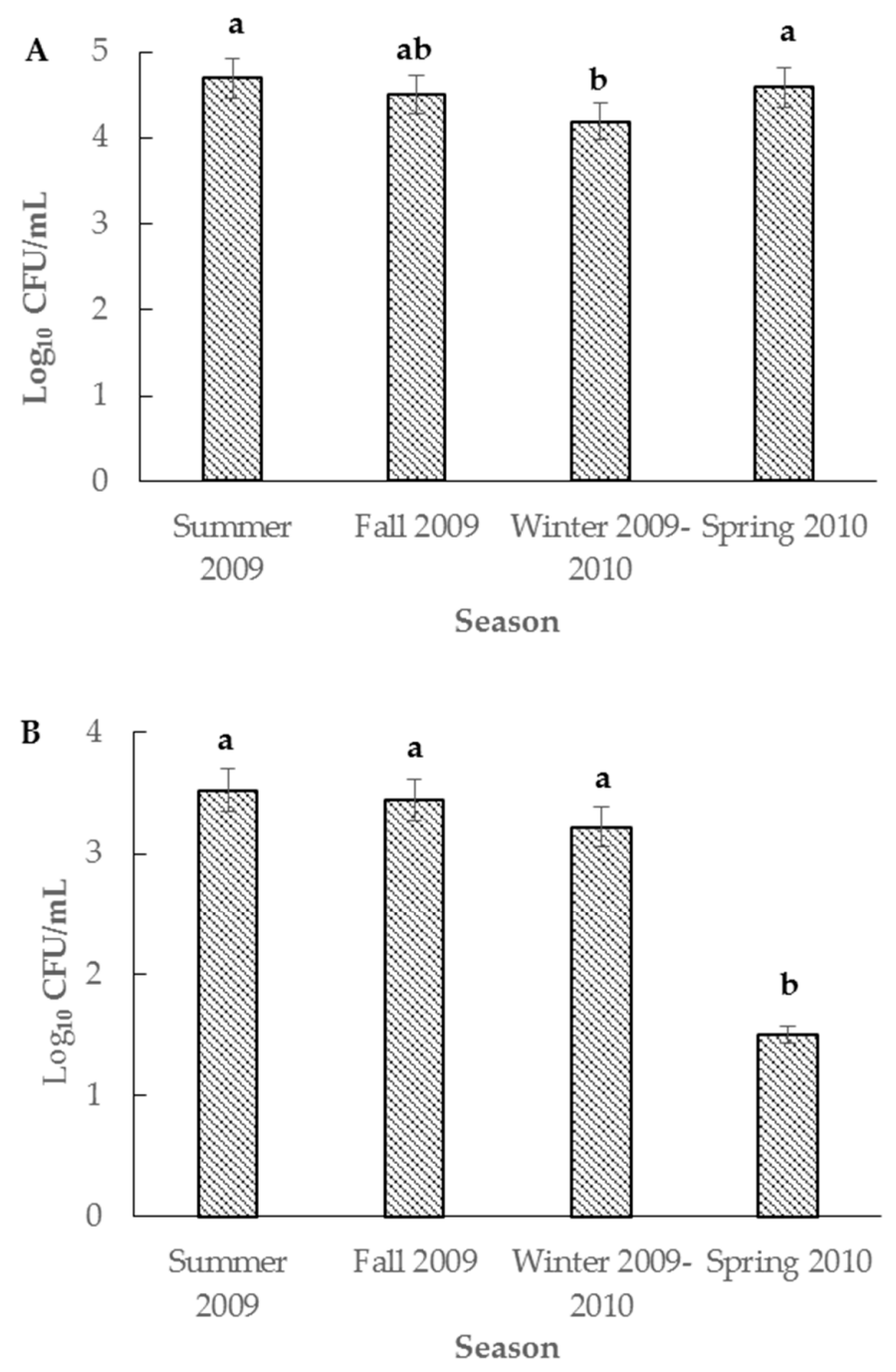

Figure 1. Total coliforms (A) and presumptive E. coli (B) population in nopal juices collected during June 2009 and May 2010. In total, 162 samples were analyzed: summer, 42 samples; fall, 45 samples; winter, 45 samples; and spring, 30 samples. Means with the same letter are not statistically different.

In our study, 62 presumptive colonies of Salmonella were isolated from 29 samples using HEA agar. The biochemical characterization identified 57 of these isolates as Citrobacter freundii and five as Proteus mirabilis. When analyzed by the automated system, the identity of the strains of Citrobacter resulted as C. youngae (33 strains), C. freundii (five strains), unidentified species between C. youngae and $C$. freundii (17 strains), Salmonella (one strain) and an unidentified strain (Table 3). It should be mentioned that $P$. mirabilis and the Salmonella strain were isolated from samples of nopal natural water juice collected at the local street (stand B) in the summer and fall, respectively, of 2009. Citrobacter populations were influenced by the type of juice and season of sample collection (Table 2, Figure 2). 
Table 2. Incidence of coliforms and number of enteropathogen isolates in nopal juices.

\begin{tabular}{|c|c|c|c|c|c|c|}
\hline Stand-Juice Composition & $\mathrm{pH}$ & TC $\log _{10}$ & E. coli $\log _{10}$ & Citrobacter & Proteus & Salmonella \\
\hline \multicolumn{7}{|l|}{ In building } \\
\hline Nopal, natural water & $4.9 \mathrm{abcd}$ & 4.3 cdef & $2.7 \mathrm{bc}$ & 7 & & \\
\hline Nopal, celery, orange, lemon, pineapple, and purslane & 4.5 defg & $4.8 \mathrm{abcd}$ & $3.6 \mathrm{ab}$ & 1 & & \\
\hline Nopal, oats, orange and apple & 4.5 cdefg & 4.4 cdef & $3.1 \mathrm{bc}$ & & & \\
\hline Nopal, broccoli, cabbage, asparagus and grapefruit & 4.4 defg & 4.2 def & $3.3 \mathrm{bc}$ & & & \\
\hline Nopal, aloe vera, grapefruit and xoconostle & $4.3 \mathrm{efg}$ & 4.2 cdef & $3.4 \mathrm{~b}$ & & & \\
\hline Nopal, garlic, lemon, parsley and pineapple & $4.3 \mathrm{efg}$ & $3.3 \mathrm{~g}$ & $2.1 \mathrm{~cd}$ & & & \\
\hline Nopal, celery, sugar beet and pineapple & 4.5 cdefg & $4.9 \mathrm{abcd}$ & $3.8 \mathrm{ab}$ & 7 & & \\
\hline Nopal, celery, lemon, parsley and carrot & $5.1 \mathrm{ab}$ & $5.6 \mathrm{a}$ & $4.8 \mathrm{a}$ & 10 & & \\
\hline Nopal, squash, orange, cucumber and pineapple & 4.4 defg & 4.7 bcde & $3.4 \mathrm{~b}$ & & & \\
\hline Nopal, natural water, aloe vera and xoconostle & 4.6 bcdefg & 4.4 cdef & $3.1 \mathrm{bc}$ & 18 & & \\
\hline Nopal, celery, parsley and pineapple & 4.5 cdefg & $5.1 \mathrm{abc}$ & $3.8 \mathrm{ab}$ & 2 & & \\
\hline Nopal, prunes, flaxseed, papaya and orange & 4.7 bcdef & 4.3 cdef & $3.2 \mathrm{bc}$ & 2 & & \\
\hline Nopal, natural water, parsley and sugar beet & 4.7 bcdefg & $4.7 \mathrm{abcd}$ & $3.4 \mathrm{bc}$ & & & \\
\hline Nopal, celery, honey, orange and pineapple & $4.1 \mathrm{~g}$ & $5.3 \mathrm{ab}$ & $1.3 \mathrm{de}$ & & & \\
\hline Nopal, oats, apple, honey and orange & 4.5 cdefg & 4.6 bcde & $1.2 \mathrm{de}$ & & & \\
\hline Nopal, alfalfa, lemon, honey, orange and pineapple & $4.2 \mathrm{fg}$ & $4.9 \mathrm{abcd}$ & $1.0 \mathrm{e}$ & & & \\
\hline Nopal, natural water, aloe vera and xoconostle & $4.3 \mathrm{efg}$ & 4.1 defg & 1.0 de & & & \\
\hline Nopal, olive oil, sugar beet, flax, papaya, honey, orange & $5.0 \mathrm{abc}$ & $4.8 \mathrm{bcd}$ & $0.9 \mathrm{e}$ & & & \\
\hline Nopal, aloe vera, grape fruit and xoconostle & 4.6 bcdefg & 4.7 bcde & $1.3 \mathrm{~g}$ & 3 & & \\
\hline Nopal, prunes, flaxseed, honey, papaya and orange & 4.8 abcd & 3.9 efg & $1.0 \mathrm{e}$ & & & \\
\hline \multicolumn{7}{|l|}{ In street booth } \\
\hline Nopal, natural water & $4.9 \mathrm{abcd}$ & 4.5 cdef & $3.1 \mathrm{bc}$ & 5 & 5 & 1 \\
\hline Nopal, celery, orange, parsley and pineapple & 4.5 defg & $3.7 \mathrm{fg}$ & $2.89 \mathrm{bc}$ & & & \\
\hline
\end{tabular}

Means with same letter are not statistically different. 
Table 3. Biochemical characterization of presumptive Salmonella strains isolated from nopal juices.

\begin{tabular}{|c|c|c|c|c|}
\hline \multirow{2}{*}{ Month } & \multirow{2}{*}{ Stand-Juice } & \multirow{2}{*}{$\begin{array}{l}\text { Number of } \\
\text { Strains }\end{array}$} & \multicolumn{2}{|c|}{ Characterization } \\
\hline & & & Biochemical & VITEK 2 \\
\hline June & $\begin{array}{l}\text { A-Nopal, natural water, } \\
\text { aloe vera and xoconostle }\end{array}$ & 4 & C. freundii (4) $\stackrel{¥}{\text { }}$ & $\begin{array}{c}\text { C. youngae/C. freundii (3) } \\
\text { C. youngae (1) }\end{array}$ \\
\hline \multirow[t]{2}{*}{ July } & $\begin{array}{l}\text { A-Nopal, celery, lemon, } \\
\text { parsley and carrot }\end{array}$ & 2 & C. freundii (2) & C. youngae/C. freundii (2) \\
\hline & $\begin{array}{l}\text { A-Nopal, natural water, } \\
\text { aloe vera and xoconostle }\end{array}$ & 3 & C. freundii (3) & $\begin{array}{c}\text { Unidentified (1) } \\
\text { C. youngae/C. freundii (2) }\end{array}$ \\
\hline \multirow[t]{6}{*}{ August } & $\begin{array}{l}\text { A-Nopal, celery, orange, } \\
\text { lemon, pineapple, } \\
\text { and purslane }\end{array}$ & 1 & C. freundii (1) & C. freundii (1) \\
\hline & $\begin{array}{l}\text { A-Nopal, celery, sugar beet } \\
\text { and pineapple }\end{array}$ & 5 & C. freundii (5) & C. youngae/C. freundii (4) \\
\hline & & & & C. freundii (1) \\
\hline & $\begin{array}{l}\text { A-Nopal, celery, lemon, } \\
\text { parsley and carrot }\end{array}$ & 1 & C. freundii (1) & C. youngae (1) \\
\hline & $\begin{array}{l}\text { A-Nopal, prunes, flaxseed, } \\
\text { papaya and orange }\end{array}$ & 2 & C. freundii (2) & C. youngae/C. freundii (1) \\
\hline & B-Nopal, natural water & 3 & C. freundii (3) & $\begin{array}{c}\text { C. youngae (1) } \\
\text { Salmonella }(1) \\
\text { C. youngae/C. freundii (2) }\end{array}$ \\
\hline \multirow[t]{2}{*}{ September } & $\begin{array}{l}\text { A-Nopal, celery, lemon, } \\
\text { parsley and carrot }\end{array}$ & 7 & C. freundii (7) & C. youngae (7) \\
\hline & $\begin{array}{l}\text { A-Nopal, natural water, } \\
\text { aloe vera and xoconostle }\end{array}$ & 1 & C. freundii (1) & C. freundii (1) \\
\hline \multirow[t]{3}{*}{ October } & $\begin{array}{l}\text { A-Nopal, celery, sugar beet } \\
\text { and pineapple }\end{array}$ & 2 & C. freundii (2) & C. youngae (2) \\
\hline & $\begin{array}{l}\text { A-Nopal, celery, lemon, } \\
\text { parsley and carrot }\end{array}$ & 2 & C. freundii (2) & C. youngae (2) \\
\hline & B-Nopal, natural water & 1 & C. freundii (1) & C. youngae (1) \\
\hline November & $\begin{array}{l}\text { A-Nopal, celery, parsley } \\
\text { and pineapple }\end{array}$ & 2 & C. freundii (2) & C. youngae (2) \\
\hline \multirow[t]{3}{*}{ December } & A-Nopal, natural water & 5 & C. freundii (5) & C. youngae (5) \\
\hline & $\begin{array}{l}\text { A-Nopal, natural water, } \\
\text { aloe vera and xoconostle }\end{array}$ & 5 & C. freundii (5) & $\begin{array}{l}\text { C. freundii (2) } \\
\text { C. youngae/C. freundii (3) }\end{array}$ \\
\hline & B-Nopal, natural water & 2 & C. freundii (2) & C. youngae (2) \\
\hline January & $\begin{array}{l}\text { A-Nopal, natural water, } \\
\text { aloe vera and xoconostle }\end{array}$ & 2 & C. freundii (2) & C. youngae (2) \\
\hline February & A-Nopal, natural water & 2 & C. freundii (2) & C. youngae (2) \\
\hline March & $\begin{array}{l}\text { A-Nopal, celery, lemon, } \\
\text { parsley and carrot }\end{array}$ & 1 & C. freundii (1) & C. youngae (1) \\
\hline April & $\begin{array}{l}\text { A-Nopal, natural water, } \\
\text { aloe vera and xoconostle }\end{array}$ & 1 & C. freundii (1) & C. youngae (1) \\
\hline May & $\begin{array}{l}\text { A-Nopal, aloe vera, grape } \\
\text { fruit and xoconostle }\end{array}$ & 3 & C. freundii (3) & C. youngae (3) \\
\hline
\end{tabular}




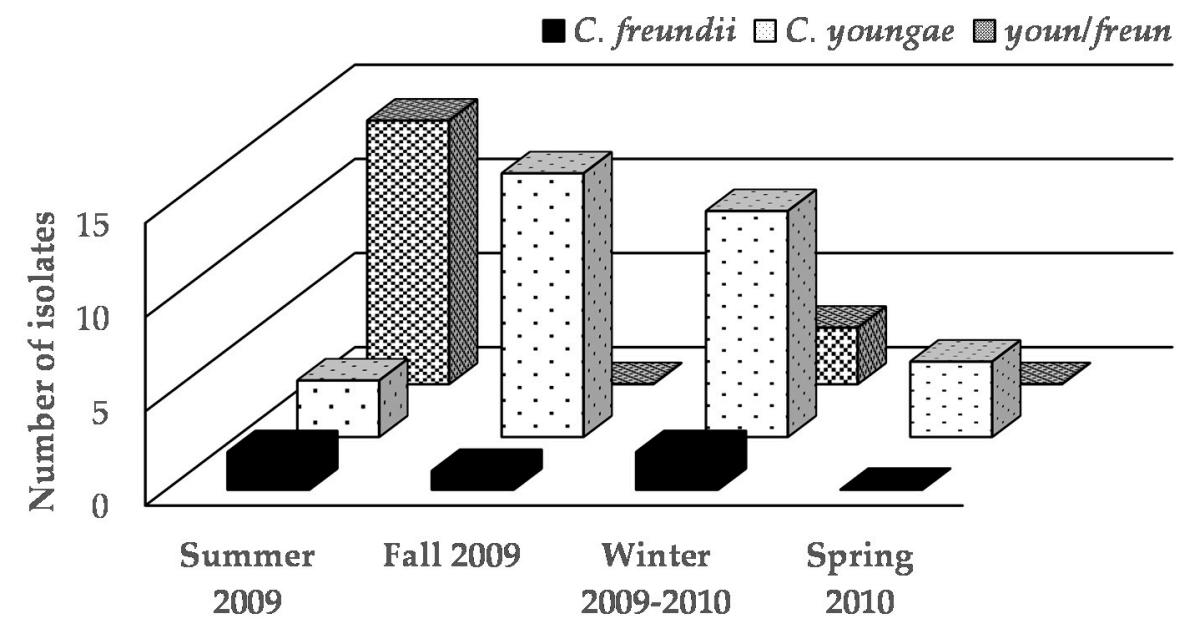

Figure 2. Citrobacter species isolated from fresh nopal juices collected during June 2009 and May 2010; youn/freun corresponds to strains of indefinite species between C. youngae and C. freundii.

The genera of Proteus and Citrobacter are related to Salmonella, all pertaining to the family Enterobacteriaceae. In general, Citrobacter and Salmonella are difficult to distinguish by biochemical analysis [23]; even in their serological characterization, crossed reactions can be identified in the analysis of the somatic antigens $\mathrm{O}$ [24]. We used a larger number of biochemical tests and a commercial identification system to precisely differentiate these bacteria as suggested by $\mathrm{O}^{\prime}$ Hara et al. [25].

The Salmonella strain was characterized as the S. enterica serotype Javiana (S. Javiana) through somatic and flagellar agglutination; the PCR reaction generated a positive result of amplification with a band (275 bp) similar to that obtained with the positive control (S. Typhimurium ATCC23564) (Figure 3). Although the presence of $S$. Javiana has been reported previously in vegetable nopal [6], the potential source of Salmonella contamination was obscure in this study. In addition to water quality and hygienic practices, the presence of flies at both stands could have also contributed to Salmonella contamination in the fresh juice. Contamination of fresh nopal juice with Proteus, Citrobacter and Salmonella represents a serious threat to healthy and immuno-compromised consumers who consume it for health benefits. Although P. mirabilis and C. freundii are considered opportunist pathogens [16], they can cause diseases in humans such as neonatal meningitis and urinary tract infections, respectively, in immuno-compromised people [26,27]. It is well known that the consumption of fresh unpasteurized juices, even with a low $\mathrm{pH}$, represents a risk for human health. Salmonella was the causative agent of infections in $64 \%$ of the foodborne outbreaks associated with fresh juice [12]. Castillo et al. [9] reported the presence of Salmonella in $20 \%$ of fresh orange juice samples collected at local street stands in Guadalajara, Mexico. It should be pointed out that $S$. Javiana is a highly virulent serotype, which has been implicated in various outbreaks associated with the consumption of contaminated fruits, vegetables and other products [28].

The consumption of fresh fruit and vegetable juices is widely popular with consumers because of their purported health benefits. In general, fruit juice consumers have the idea that fresh fruit juices are of minimal concern for microbial safety because of the very low probability of finding human pathogens in these products due to their low $\mathrm{pH}$ and high acidity. However, several juice-related outbreaks of salmonellosis have been registered during the last two decades [29-31]. This indicates that Salmonella has the ability to tolerate acidic conditions for survival and causes disease upon consumption of the juice. 


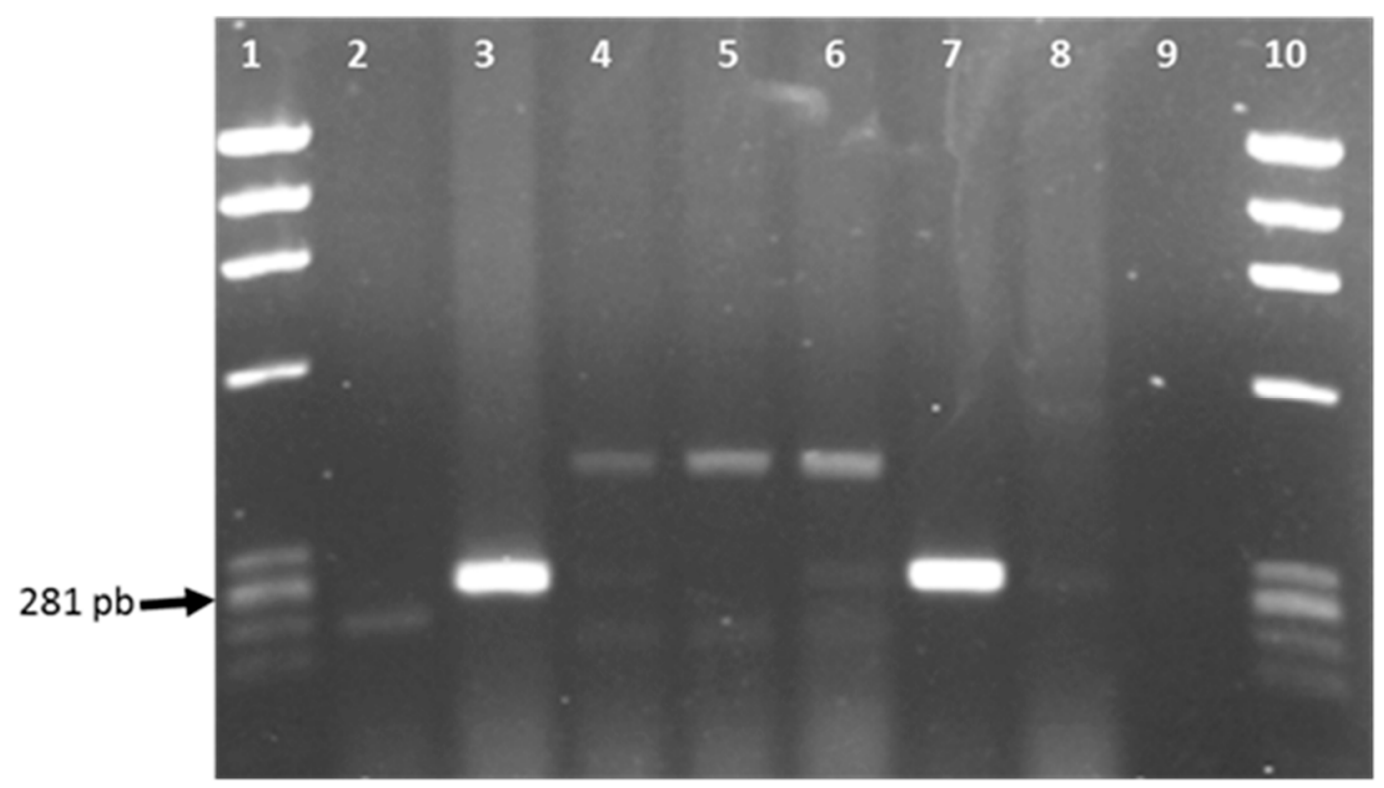

Figure 3. PCR amplification products with Sal 3 and Sal 4 of cell lysates. Lanes: 1 and 10, Marker DNA/Hae; Lanes 2, 4 and 5, strains of indeterminate species of C. youngae and C. freundii; Lane 3, strain of S. Javiana; Lane 6, strain of C. freundii; Lane 7, S. Typhimurium ATCC23564; Lane 8, E. coli 042; Lane 9, water.

\section{Conclusions}

The microbiological quality of the fresh juices prepared with vegetable nopal, blended with fresh squeezed citrus juice and/or a mix of fresh fruits and vegetables, in commercial establishments in Texcoco, State of Mexico, is unacceptable based on the persistence of enteric microorganisms in the juices. These enteropathogens can survive and cause serious infections in healthy and immuno-compromised people. The monitoring of the microbial quality of the fresh products and water used in juice preparation, the potential terminal treatment to reduce microbial populations in fresh juice, personal hygiene, and sanitation practices at vendor stands are important control points to be considered for reducing the risks to human health. The information generated in this study is relevant for developing new interventions for bacterial reduction in fresh juice and for risk assessment for human health represented by the consumption of fresh unpasteurized nopal juice.

Acknowledgments: The research work was supported by Graduate College, Mexico, and partially funded by the Mexican National Council for Science and Technology (CONACYT) through the scholarship 160232 given to the second author during her doctoral studies.

Author Contributions: Ana María Hernández-Anguiano, Patricia Landa-Salgado, Carlos Alberto Eslava-Campos, and Jitendra Patel performed the experiments and Mateo Vargas-Hernández contributed to statistical data analysis. All authors contributed to the writing of the manuscript.

Conflicts of Interest: The authors declare no conflict of interest.

\section{References}

1. Feugang, J.; Konarski, A.P.; Zou, D.; Stintzing, F.C.; Zou, C. Nutritional and medicinal use of cactus pear (Opuntia spp.) cladodes and fruits. Front. Biosci. 2006, 11, 2574-2589. [CrossRef] [PubMed]

2. Galati, E.M.; Monforte, M.T.; Tripodo, M.M.; d'Aquino, A.; Mondello, M.R. Antiulcer activity of Opuntia ficus-indica (L.) Mill. (Cactaceae): Ultrastructural study. J. Ethnopharmacol. 2001, 76, 1-9. [CrossRef]

3. Galati, E.M.; Monforte, M.T.; Miceli, N.; Mondello, M.R.; Taviano, M.R.; Galluzzo, M.; Tripodo, M.M. Opuntia ficus-indica (L.) Mill. Mucilages show cytoprotective effect on gastric mucosa in rat. Phytother. Res. 2007, 21, 344-346. [CrossRef] [PubMed] 
4. Galati, E.M.; Mondello, M.R.; Monforte, M.T.; Galluzzo, M.; Miceli, N.; Tripodo, M.M. Effect of Opuntia ficus-indica (L.) Mill. Cladodes in the wound-healing process. J. Prof. Assoc. Cactus 2003, 5, $1-16$.

5. Basurto, S.D.; Lorenzana, J.M.; Magos, G.A. Utilidad del nopal para el control de la glucosa en la diabetes mellitus tipo 2. Rev. Fac. Med. UNAM 2006, 49, 157-162.

6. Hernández, A.A.M.; Landa, S.P.; Mora, A.G.; Eslava, C.C.A.; Call, J.E.; Porto-Fett, A.C.S.; Luchansky, J.B. Characterization of Salmonella spp. from nopal leaves and associated soil and water samples in Morelos, Mexico. In Proceedings of the International Association for Food Protection (IAFP) Annual Meeting, Grapevine, TX, USA, 3-6 August 2008; pp. 74-75.

7. Hirotani, H.; Naranjo, J.; Motoyoqui, P.G.; Gerb, C.P. Demonstration of indicator of microorganisms on surface of vegetables on the market in the United States and Mexico. J. Food Sci. 2002, 67, 1847-1850. [CrossRef]

8. Quiroz-Santiago, C.; Rodas-Súarez, O.R.; Vázquez, Q.C.R.; Fernández, F.J.; Quiñones-Ramírez, E.I.; Vázquez-Salinas, C. Prevalence of Salmonella in vegetables from México. J. Food Prot. 2009, 72, 1279-1282. [CrossRef] [PubMed]

9. Castillo, A.; Villarruel-López, A.; Navarro-Hidalgo, V.; Martínez-González, N.E.; Torres-Vitela, M.R. Salmonella and Shigella in freshly squeezed orange juice fresh oranges, and wiping cloths collected from public markets and street booths in Guadalajara, México: Incidence and comparison and analytical routes. J. Food Prot. 2006, 69, 2595-2599. [CrossRef] [PubMed]

10. Lewis, J.E.; Thompson, P.; Rao, B.N.; Kalavati, C.; Rajanna, B. Human bacteria in street vended fruit juices: A case study of Visakhapatnam city, India. Internet J. Food Saf. 2006, 8, 35-38.

11. Parish, M.E. Public health and nonpasteurized fruit juices. Crit. Rev. Microbiol. 1997, 23, 109-119. [CrossRef] [PubMed]

12. Parish, M.E. Food safety issues and the microbiology of fruit beverages and bottled water. In Microbiologically Safe Foods; Heredia, N., Wesley, I., Garcia, S., Eds.; John Wiley and Son Inc.: Hoboken, NJ, USA, 2009; pp. 291-304.

13. Norma Oficial Mexicana. NOM-113-SSA-1994. Bienes y Servicios. Método Para la Cuenta de Microorganismos Coliformes Totales en Placa. Diario Oficial de la Federación, México. Available online: http://www.salud.gob.mx/unidades/cdi/nom/113ssa14.html (accessed on July 2008).

14. Norma Oficial Mexicana. NOM-114-SSA1-1994. Bienes y Servicios. Método Para la Determinación de Salmonella en Alimentos. Diario Oficial de la Federación, México. Available online: http:/ /www.salud.gob. $\mathrm{mx} /$ unidades/cdi/nom/114ssa14.html (accessed on July 2008).

15. Winn, W.C.; Allen, S.D.; Janda, W.M.; Koneman, E.W.; Procop, G.W.; Schreckenberger, P.C.; Woods, G.L. Diagnóstico Microbiológico, texto y atlas en Color, 6th ed.; Editorial Medica Panamericana: Buenos Aires, Argentina, 2008; p. 1475.

16. Terragno, R.; Caffer, M.A.I.; Bruno, S.; Binsztein, N. Parte I: Aislamiento Identificación y Serotipificación de Salmonella, Manual de Procedimientos; Instituto Nacional de Enfermedades Infecciosas (INEI), Departamento de Bacteriología: Buenos Aires, Argentina, 2003; p. 56.

17. Popoff, M.; Bockemuhl, J.; McWorther-Murlin, A. The Kauffmann-White scheme. Res. Microbiol. 1991, 34, 1029-1033. [CrossRef]

18. Rahn, K.; De Grandis, S.A.; Clarke, R. Amplification of invA gene sequence of Salmonella typhimurium by polymerase chain reaction as a specific method of detection of Salmonella. Mol. Cell. Probes 1992, 6, 271-279. [CrossRef]

19. Mexican Official Standards (NOM). Environmental Health: Water for Human Use and Consumption. Permissible Limits of Quality and Treatments Must Undergo for Water Purification. Available online: http://www.salud.gob.mx/unidades/cdi/nom/127ssa14.html (accessed on July 2008).

20. Food Safety Modernitation Act (FSMA). Available online: http://www.gpo.gov/fdsys/pkg/PLAW111publ353/pdf/PLAW-111publ353.pdf (accessed on 29 June 2016).

21. Berger, C.N.; Sodha, S.V.; Shaw, R.K.; Griffin, P.M.; Pink, D.; Hand, P.; Frankel, G. Fresh fruit and vegetables as vehicles for the transmission of human pathogens. Environ. Microbiol. 2010, 12, 2385-2397. [CrossRef] [PubMed]

22. Winfield, M.D.; Groisman, E.A. Role of nonhost environments in the lifestyles of Salmonella and Escherichia coli. Appl. Environ. Microb. 2003, 69, 3687-3694. [CrossRef] 
23. Changla, A.H.; Borczyk, A.A.; Aldom, J.E.; Dalla Rosa, S.; Cole, D.D. Evaluation of the L-pyrrolidonyl-beta-naphthylamide hydrolysis test for the differentiation of members of the families Enterobacteriaceae and Vibrionaceae. J. Clin. Microbiol. 1993, 31, 1946-1948.

24. Reyes, R.E.; Ramírez-Saad, H.; Pérez, J.; Meléndez, E.; Navaroo, A.; Murata, C.; Cravioto, A. Intra-strain variation of lipopolysaccharides from Citrobacter freundii E97750 by in vitro passages. Afr. J. Microbiol. Res. 2010, 4, 1324-1331.

25. O'Hara, C.; Roman, S.B.; Miller, J.M. Ability of commercial identification systems to identify newly recognized species of Citrobacter. J. Clin. Microbiol. 1995, 33, 242-245. [PubMed]

26. Ronald, A. The etiology of urinary tract infection: Traditional and emerging pathogens. Dis. Mon. 2003, 49, 71-82. [CrossRef] [PubMed]

27. Doran, T.I. The role of Citrobacter in clinical disease of children: Review. Clin. Infect. Dis. 1999, $28,384-394$. [CrossRef] [PubMed]

28. Jackson, B.R.; Griffin, P.M.; Cole, D.; Walsh, K.A.; Chai, S.J. Outbreak-Associated Salmonella enterica Serotypes and Food Commodities, United States, 1998-2008. Emerg. Infect. Dis. 2013, 19, 1239-1244. Available online: www.cdc.gov/eid (accessed on 1 March 2016). [CrossRef] [PubMed]

29. Cook, K.A.; Dobbs, T.E.; Hlady, W.G.; Wells, J.G.; Barrett, T.J.; Puhr, N.D.; Lancette, G.A.; Bodager, D.W.; Toth, B.L.; Genese, C.A.; et al. Outbreak of Salmonella serotype Hartford infections associated with unpasteurized orange juice. JAMA 1998, 280, 1504-1509. [CrossRef] [PubMed]

30. Krause, G.; Terzagian, R.; Hammond, R. Outbreak of Salmonella serotype Anatum infection associated with unpasteurized orange juice. South. Med. J. 2001, 94, 1168-1172. [CrossRef] [PubMed]

31. Jain, S.; Bidol, S.A.; Austion, J.L.; Berl, E.; Elson, F.; Williams, M.L.; Deasy, M.; Moll, M.E.; Rea, V.; et al. Multistate Outbreak of Salmonella Typhimurium and Saintpaul Infections Associated with Unpasteurized Orange Juice-United States, 2005. Clin. Infect. Dis. 2009, 48, 1065-1071. [CrossRef] [PubMed]

(C) 2016 by the authors; licensee MDPI, Basel, Switzerland. This article is an open access article distributed under the terms and conditions of the Creative Commons Attribution (CC-BY) license (http://creativecommons.org/licenses/by/4.0/). 